\title{
Study of the Rat Adrenal Renin-Angiotensin System at a Cellular Level
}

Cho-Yen Chiou, Gordon H. Williams, and Imre Kifor

Endocrine-Hypertension Division and the Department of Medicine, Brigham and Women's Hospital and Harvard Medical School, Boston, Massachusetts 02115

\section{Abstract}

To address the question as to how zona glomerulosa (ZG) cell angiotensin II (Ang II) secretion is regulated, we developed an immuno-cell blot assay to measure its secretion from single cells. We compared these results with those obtained from population studies using a superfusion system. Modulation of Ang II secretion was investigated acutely (by administrating potassium $\left[\mathrm{K}^{+}\right]$or captopril) and chronically (by feeding the animals low or high sodium diets). The area of secretory cells, halo areas, and halo intensities varied widely but were highly significantly correlated $(P$ $<0.001$ ) with each other. A disproportionate amount of Ang II was secreted by a small number of large cells. When $\mathrm{K}^{+}$concentration was increased from 3.6 to $9 \mathrm{mM}$, superfused ZG cells increased their Ang II secretion 2.32 \pm 0.59 fold. Administration of captopril reduced the $\mathrm{K}^{+}$-stimulated Ang II secretion $1.24 \pm 0.07$-fold. These findings were reflected in the cell blot assay as a change in the frequency distribution of halo area by $\mathrm{K}^{+}$and captopril in the same direction as in the population study. In both conditions, the percentage of secretory cells did not change significantly from control. Superfused $\mathrm{ZG}$ cells from rats on a low sodium diet secreted $1.85 \pm 0.58$-fold more Ang II than cells from sodium-loaded rats $(P<0.05, n=6)$. The cell blot assay confirmed these findings with sodium restriction significantly increasing $(P<0.001)$ both the halo area and its frequency distribution to a larger portion of high secreting cells. However, in contrast to acute treatment with $\mathrm{K}^{+}$or captopril, the number of secretory cells also doubled. Thus, the individual ZG cell uses two mechanisms to modify Ang II production. In response to acute stimulation and suppression, the amount of Ang II secreted per cell is modified without changing the number of secretory cells. With chronic stimulation, both the amount of Ang II secreted per cell and the number of secretory cells increase. (J. Clin. Invest. 1995. 96:1375-1381.) Key words: angiotensin II • secretion • potassium • captopril • sodium intake

\section{Introduction}

Multiple studies document the presence of a local renin-angiotensin system in the adrenal gland (1-8). The locally generated

Address correspondence to Imre Kifor, Ph.D., Endocrine-Hypertension Division, Brigham and Women's Hospital, 221 Longwood Avenue, Boston, MA 02115. Phone: 617-732-5661; FAX: 617-732-5764.

Received for publication 18 November 1994 and accepted in revised form 5 June 1995.

J. Clin. Invest.

(C) The American Society for Clinical Investigation, Inc.

0021-9738/95/09/1375/07 \$2.00

Volume 96, September 1995, 1375-1381 angiotensin II (Ang II) ${ }^{1}$ may play a significant role in the regulation of aldosterone secretion through a paracrine or autocrine effect. This notion is supported by the following observations: ( $a$ ) superfused enzymatically dispersed zona glomerulosa (ZG) cells actively secrete Ang II in a pulsatile pattern, and the amount of Ang II released correlates well with aldosterone secretion $(9,10)$; $(b)$ maneuvers designed to modify aldosterone synthesis and secretion, e.g., change of potassium $\left(\mathrm{K}^{+}\right)$ concentration or dietary sodium intake, affect adrenal renin activity similarly ( 3 ); (c) elevation of $\mathrm{K}^{+}$concentration increased Ang II secretion from superfused ZG cells $(9)$; and $(d)$ losartan, a type 1 Ang II receptor ( $\left.\mathrm{AT}_{1}\right)$ antagonist, inhibited $\mathrm{K}^{+}$-induced increase in aldosterone secretion (11). Since all of these studies were performed using populations of cells, it remains unclear how this local renin-angiotensin system is regulated at the single cell level. Is Ang II actually secreted from single cells? If yes, how is its secretion modulated? Theoretically, an increase in Ang II secretion could be achieved by increasing the number of Ang II-secreting cells or the amount of Ang II secreted by individual cells, or both. To address these questions, we developed a cell immuno-cell blot assay to measure secretion of Ang II from individual cells. Using this assay, we assessed the effect of agents that acutely stimulate $\left(\mathrm{K}^{+}\right)$or suppress (captopril) Ang II secretion and maneuvers (changes in sodium intake) that chronically modify its secretion. Finally, we correlated these results with those obtained from similar studies using populations of ZG cells.

\section{Methods}

Preparation of enzymatically dispersed ZG cells. Adrenal glands were obtained from female Sprague-Dawley rats (Charles River Laboratory, Wilmington, MA) of undefined estrous state, age 8-10 wk, weighing 200 grams, maintained on normal $\mathrm{K}^{+}$and low $(0.02 \%)$, normal $(0.4 \%)$, or high $(1.5 \%)$ sodium diets for $5 \mathrm{~d}$. The care of the animals followed the rules and procedures approved by the Animal Care Committee of Harvard Medical School. After the rats were killed by decapitation, the adrenal glands were immediately dissected on an ice-cold platform to yield capsular zona glomerulosa and decapsular zona fasciculata/medulla tissue. The capsules were then treated with a mixture of $1 \mathrm{mg} / \mathrm{ml}$ collagenase, $0.5 \mathrm{mg} / \mathrm{ml}$ dispase (Boehringer Mannheim Corp., Indianapolis, IN), and $0.5 \mathrm{mg} / \mathrm{ml}$ DNase (Boehringer Mannheim) in Dulbecco's modified Eagle medium (DME) (Gibco Laboratories, Grand Island, NY) containing $0.1 \%$ bovine serum albumin (BSA) (Boehringer Mannheim), buffered with $25 \mathrm{mM}$ sodium bicarbonate $/ 5 \% \mathrm{CO}_{2}$ in air at $37^{\circ} \mathrm{C}$ for $1 \mathrm{~h}$. The collagenase with low trypsin-like activity was selected previously and tested to yield cells with a high rate of viability, attachment, and basal and stimulated secretion. To foster consistent and reproducible results for a longer period of time, a larger pool of the selected collagenase was stored at $-20^{\circ} \mathrm{C}$. The capsules were gently moved in

1. Abbreviations used in this paper: Ang I, II, and III, angiotensin I, II, and III; Ang II $_{\text {ir }}$, immunoreactive Ang II; IGV, integrated gray value; ZG, zona glomerulosa. 
and out of a wide mouth 1-ml pipette tip 30 times one-half way through and at the end of the incubation. For the superfusion study, the dispersed cells were washed twice with medium 199 containing $3.6 \mathrm{mM} \mathrm{K}^{+}, 25$ $\mathrm{mM}$ sodium bicarbonate $/ 5 \% \mathrm{CO}_{2}$ in the atmosphere, $0.1 \% \mathrm{BSA}$, mixed with preswollen Sephadex G15 (Sigma Immunochemicals, St. Louis, MO), loaded into superfusion chambers on top of a 5- $\mu \mathrm{m}$ nylon filter, and superfused without any delay. Two channels were used in each experiment. For the study of $9 \mathrm{mM} \mathrm{K}^{+}$stimulation and captopril treatment, one channel was used as control and the other as the treatment channel. Usually $\sim 4-5 \times 10^{6}$ cells were placed in each chamber (10 rats on normal sodium diet for each experiment). For the diet studies, each chamber contained cells obtained from one rat on either the high or low sodium diet. For the cell blot assay, the dispersed cells were filtered through a $40-\mu \mathrm{m}$ nylon mesh to remove cell clumps. The cells were washed twice with DME containing $0.025 \%$ BSA. Cell viability was determined by trypan blue exclusion test before the superfusion or cell blot experiment. The experiments were carried out only when $>90 \%$ of cells in the preparation exclude trypan blue. Then, a cell count was determined.

Measuring Ang II secretion by superfusion of ZG cells. The superfusion system of Forma Scientific (Marietta, $\mathrm{OH}$ ) was used. The volume of the superfusion chamber was $0.5 \mathrm{ml}$ with a diameter of $9 \mathrm{~mm}$. The flow rate was $0.2 \mathrm{ml} / \mathrm{min} / \mathrm{chamber}$ at $37^{\circ} \mathrm{C}$. Medium 199 containing $0.1 \%$ BSA and $3.6 \mathrm{mM}$ potassium was used for superfusion. This medium was buffered with $25 \mathrm{mM}$ sodium bicarbonate in equilibrium with air containing $5 \% \mathrm{CO}_{2}$. To reduce the nonspecific binding of the secreted peptides to the hardware, the superfusion system was perfused before each experiment for $30 \mathrm{~min}$ with medium. After viability testing and cell counting, the ZG cells were mixed with $0.2 \mathrm{ml}$ preswollen Sephadex G10 (Pharmacia AB, Uppsala, Sweden), divided into two equal aliquots, and loaded into superfusion chambers on top of a 5- $\mu \mathrm{m}$ nylon filter. The residual space was filled with additional Sephadex beads, and the superfusion started without delay. Two parallel channels were used in each experiment. The control channel was superfused with the reference medium (medium 199, usually for $270 \mathrm{~min}$ ). The experimental channel was superfused for the initial $90 \mathrm{~min}$ with the reference medium, then for $120 \mathrm{~min}$ with the reference medium containing additional test substances such as captopril, or an increased concentration of potassium, and followed by a superfusion with reference medium. The effect of sodium intake on Ang II secretion by ZG cells was determined by superfusion using medium 199 containing $3.6 \mathrm{mM}$ potassium.

After the superfusate exited the chamber, an equal volume of inhibitor solution was added to the superfusate, using a micro $T$ joint. The inhibitor solution consisted of EDTA $5 \mathrm{mM}$, phenylmethylsulfonyl fluoride (PMSF) $200 \mu \mathrm{M}$, and captopril $200 \mu \mathrm{M}$. Collection of superfusate was started $45 \mathrm{~min}$ after superfusion began. The samples were collected separately for each channel in 15-min aliquots in polyethylene tubes containing $150 \mu \mathrm{l}$ of $10 \%$ glycerol and $2 \%$ phosphoric acid using a thermostated $\left(0^{\circ} \mathrm{C}\right)$ fraction collector. The aliquots were frozen quickly in a mixture of dry ice and ethanol and lyophilized.

Radioimmunoassay (RIA) of Ang II. The lyophilized samples were redissolved in $3 \mathrm{ml}$ of deionized water. An aliquot of medium 199 with the inhibitor mixture was also lyophilized and redissolved in deionized water in the same concentration as the samples and was used as an assay buffer for the RIA standard curves. We used a double antibody method for Ang II and Ang I RIA. Since the anti-Ang II antibody (Arnel Inc., New York) cross-reacted $100 \%$ with Ang III, the term immunoreactive Ang II (Ang II $_{\text {ir }}$ ) was used. The anti-Ang II antibody had a $0.1 \%$ cross-reactivity with Ang I. The second antibody was a donkey anti-rabbit immunoglobulin, bound to a magnetic bead carrier (Amerlex M separation reagent; Amersham Corp., Arlington Heights, IL). The [ $\left.{ }^{125} I\right]$ Ang II was purchased from New England Nuclear (Boston, MA). The sensitivity of the assay was $0.25 \mathrm{f} \mathrm{M} /$ sample for Ang II. The coefficients of variation at 8 and $32 \mathrm{fM}$ were $<5 \%$.

Measuring Ang II secretion by enzymatically dispersed single cells using an immuno-cell blot technique. The cell blot assay was adapted from that described by Kendall and Hymer (12) to study the secretion of prolactin from isolated lactotrophs with the following modifications.
Immediately after the cell viability check, the $\mathrm{ZG}$ cell suspension was diluted to 10,000 cells $/ \mathrm{ml}$ with DME containing $3.6 \mathrm{mM} \mathrm{K}^{+}$and $0.025 \%$ BSA. Aliquots of $20 \mu \mathrm{l}$ were preincubated on a polyvinyldiene difluoride transfer membrane (Immobilon-P) in a 96-well microtiter plate format (Multiscreen ${ }^{\mathrm{TM}}$-IP; Millipore Corp., Bedford, MA) for $30 \mathrm{~min}$ at $37^{\circ} \mathrm{C}$ and were supplied with humidified air containing $5 \% \mathrm{CO}_{2}$. Because the membrane was hydrophobic, the cell suspension remained a droplet, and the cells settled on to the membrane. The viable cells attached to the membrane and the peptides secreted by them were covalently bound to the membrane. After the preincubation, the cells in the control group were incubated for an additional $60 \mathrm{~min}$. After $30 \mathrm{~min}$ of preincubation, potassium chloride (dissolved in $2 \mu \mathrm{l}$ of medium) was gently microinjected into the droplet to increase its final concentration to a desired level. Because of the slow effect of captopril, the cell suspension was preincubated for $1 \mathrm{~h}$ with $200 \mu \mathrm{M}$ captopril and without interruption during the incubation on the transfer membrane. In this manner, the secretory cells were exposed to captopril for $150 \mathrm{~min}$. For the study of low and high sodium diet, the cells obtained from animals on a specific diet were incubated for $60 \mathrm{~min}$ after the preincubation in a medium containing $3.6 \mathrm{mM} \mathrm{K}^{+}$

After incubation, the droplets on the membrane were carefully removed, and aliquots $(20 \mu \mathrm{l})$ of $10 \mathrm{mM}$ phenylhydrazine (Sigma Immunochemicals) were added for $30 \mathrm{~min}$ to inhibit endogenous peroxidase activity. The membrane was subsequently "capped" with a mixture of $1 \%$ BSA and $1 \%$ normal goat serum (Cappel Laboratories, Durham, $\mathrm{NC}$ ) for $4 \mathrm{~h}$ to saturate the protein-binding capacity of the membrane. The membrane was then treated as with Western blotting by the following steps: (a) rabbit anti-Ang II antibody (first antibody) (Arnel Inc.) for $6 \mathrm{~h}$, at a dilution of 1:10,000; (b) affinity-purified goat anti-rabbit IgG antibody (second antibody) (Sigma Immunochemicals) for 120 min; (c) rabbit peroxidase-antiperoxidase (Amersham Corp.) for 60 min; and $(d)$ diaminobenzidine (Vector Labs, Inc., Burlingame, CA) as substrate for $15 \mathrm{~min}$, yielding a brownish color. We also have used the alkaline phosphatase-labeled second antibody which increases the sensitivity of the assay and the color development is linear over time. The antibodies and peroxidase-antiperoxidase were diluted with the capping solution. The use of test kits containing biotinylated second antibody and avidin peroxidase or avidin-alkaline phosphatase complexes is more convenient than matching individual components. We have successfully used test kits obtained from Vector Labs, Inc. and Dako Corp. (Carpinteria, CA). The optimal dilution and the incubation time with the first antibody are critical factors and are determined in preliminary experiments. At optimal dilution and incubation time, the background is negative while spots containing Ang II are clearly positive. After each step, the membrane was washed six times with PBS (Gibco Laboratories). To minimize cell displacement, we removed reagents and washing fluid with a capillary tubing attached to a microperistaltic pump set to a slow flow rate. Reagents or washing fluids were delivered using a fine Eppendorf gel loader pipette tip at a slow rate. However, a small proportion of cells was displaced. Since the secretory cells were darker than the nonsecretory cells, it was easy to identify them at the margin of the halos or far away. The number of "homeless" secretory cells and the number of spots without cells were usually similar. Finally, the membranes were air dried and mounted under glass.

Cells on each membrane were randomly examined using a Zeiss microscope coupled to a video recorder. The acquired pictures were sent to a 486 IBM-compatible computer via a frame grabber, and then analyzed using an Optimas image analysis software (BioScan, Edmonds, WA). The area of the observed objects and the integrated gray value (IGV) of pixels within this area were measured and recorded. 4, 3, and 10 independent experiments for $\mathrm{K}^{+}$, captopril, and diet manipulation, respectively, were completed. At least 100 cells were analyzed for each condition in each experiment, except in one experiment with $\mathrm{K}^{+}$treatment in which the total number of cells on the membrane was $<100$. Thus, on average, between 300 and 400 cells served as the data set for each manipulation.

Because the secretion of peptides by cells is a three-dimensional process, the amount can only, at best, be estimated semiquantitatively 


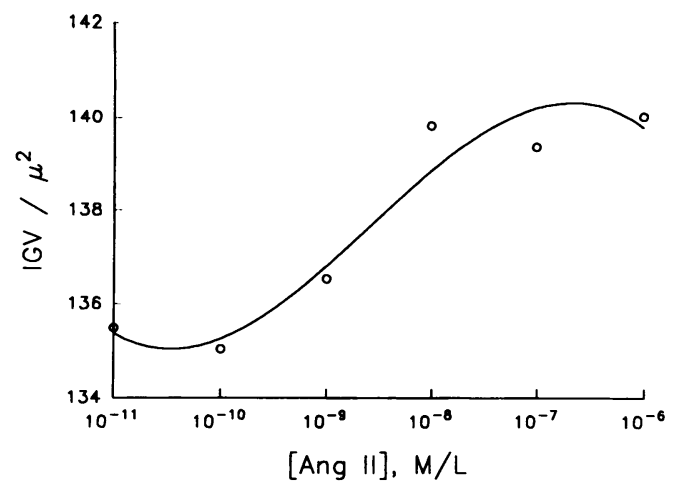

Figure 1. Ang II calibration curve. Aliquots of $1 \mu \mathrm{l}$ of $0.025 \%$ BSA/ DME with different concentrations of Ang II were placed on the membrane using a micropipette, dried, and then stained using the cell blot technique. Increasing concentrations of Ang II from $10^{-10}$ to $10^{-7} \mathrm{M}$ were associated with proportional increases in the intensity of the stain (IGV/area) (representative result from three independent experiments).

by measuring the area of secretion in the cell blot assay similar to the area of hemolysis in the hemolytic plaque assay. The cell blot assay has a theoretical advantage over the hemolytic plaque assay since it may be able to measure intensity in addition to area of secretion. Thus, IGV may be useful for more accurate quantitation of secretion. To evaluate the Ang II detection ability by our method, we placed $1-\mu 1$ aliquots of $0.025 \% \mathrm{BSA} / \mathrm{DME}$ with different concentrations of Ang II, ranging from $10^{-11}$ to $10^{-6} \mathrm{M}$, on the membrane using a micropipette and then followed the cell blot procedure. Finally, since secretory peptides have been known to be cosecreted with large carrier proteins, we evaluated the ability of this method to detect Ang II bound to BSA with a 6 atom spacer arm.

Statistics. Data are displayed as the mean \pm SEM. The significance of differences observed between control and experimental groups was calculated using paired Student's $t$ test and, where appropriate, Wilcoxon's rank sum test or Fisher exact test. The Kolmogorov-Smirnov and the equal variance tests were used to test the normality of distribution patterns.

\section{Results}

\section{Ang II secretion from single $\mathrm{ZG}$ cells}

There was a significant $(r=0.96, P<0.005)$ third order correlation between the concentration of Ang II within the droplets placed on the transfer membrane and the intensity of the spot produced (Fig. 1). This indicated that within the range of $10^{-10}$ and $10^{-7} \mathrm{M}$ Ang II the spot intensity was proportional to Ang II concentration. ZG cells were surrounded by halos of stain, which represented the secretion of Ang II from these cells (Fig. 2). The usually asymmetrical halo was produced by $\sim 20-25 \%$ of cells from the glomerulosa preparation. The cells within the halos (secretors) were also stained and were darker than the halos. The area and IGV of halos were calculated by subtracting the values of cells from those of spots (including cells). Occasionally a spot would have more than one cell inside. Some spots $(<10 \%)$ contained no cells, suggesting that they moved or were lysed during the washing procedure. Also present were cells without halos (nonsecretors) (Fig. 1). The majority of these cells stained lighter than the secretors. However, a few nonsecretors $(\sim 10 \%)$ had color reaction as intense as secretors, suggesting they may have been moved from their halo by the washing procedure. If preimmune serum or PBS containing BSA was substituted for one of the antibodies, no halo was seen. A similar effect was produced by incubation of cells with anti-Ang II antibody saturated with excessive amounts of Ang II. However, the secretory cells were still lightly stained. The area of the secretory and nonsecretory cells varied. The Kolmogorov-Smirnov and the equal variance test failed to support a normal distribution of the area of secretory cells (Fig. 3). The halo areas and IGVs also varied over a wide range. Similar to the distribution pattern of secretory cells, the Kolmogorov-Smirnov and the equal variance tests failed to sup-

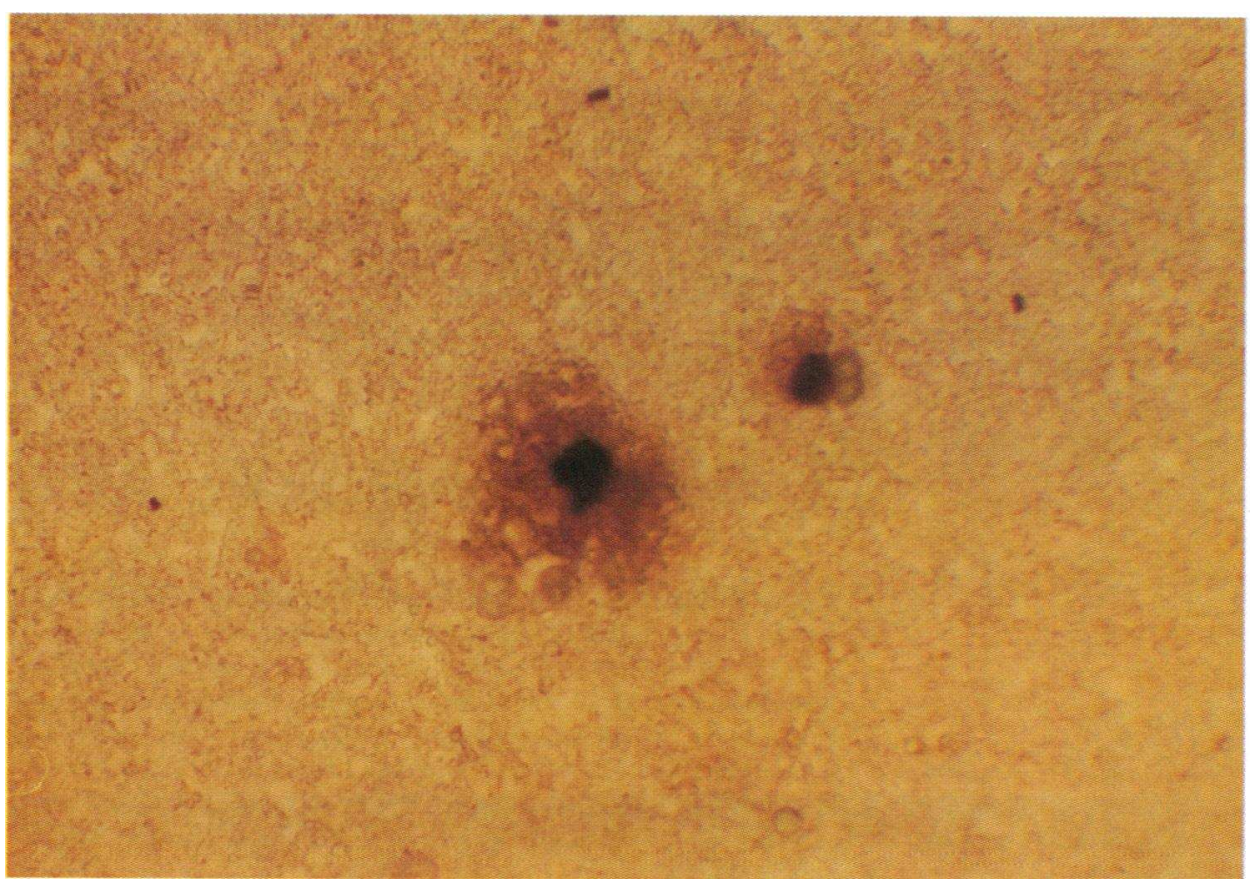

Figure 2. Ang II secretion from single isolated ZG cells. On the right is a secretory cell. The dark center is the cell, and the halo represents Ang II secreted by the cell. A cell without a halo (nonsecretor) is seen on the left. $\times 400$. 


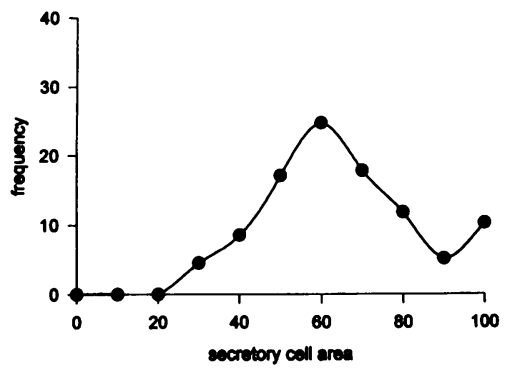

Figure 3. Frequency distribution of secretory cell area in 450 cells from six separate experiments. Animals were maintained on an ad libitum diet.

port a normal distribution of halo area generated from 450 data points pooled without selection from six experiments (Fig. 4). A highly significant correlation $\left(r=0.968, P<10^{-6}\right)$ between the halo areas and the corresponding IGVs indicates that the halo area and the halo intensity are related entities, e.g., the distribution pattern is similar and larger secretory spots are darker. For simplicity, therefore, only data using halo area are presented.

There also was a significant correlation between the area of secretory cells and the area of halos produced around the cells ( $r=0.490, P<0.0001$ ) (Fig. 5). A similar but weaker correlation $(r=0.266, P<0.0001)$ existed between the area of secretory cells and the intensity of halos. This relationship indicates that smaller secretory cells produce small halos with low intensity, while the large secretors produce larger and darker halos that contain more Ang II in the same area. Thus, the median of the halo area produced by 52 small cells with an area up to $40 \mu \mathrm{m}^{2}$ was $167 \mu \mathrm{m}^{2}$ versus a median of $519 \mu \mathrm{m}^{2}$ produced by large secretors $(n=22)$ with a cell area of 90 $\mu \mathrm{m}^{2}$ or larger where the inflection point in Fig. 3 is seen. The difference tested with the Mann-Whitney rank sum test was highly significant $(P<0.001)$.

\section{Acute response to $\mathrm{K}^{+}$and captopril}

Superfusion study. We have previously observed that increasing $\mathrm{K}^{+}$concentration in the superfusion media from 3.6 to $9 \mathrm{mM}$ increases Ang $\mathrm{II}_{\mathrm{ir}}$ secretion 1.4-fold during the first $2 \mathrm{~h}$ of superfusion (9). Two additional superfusion studies were performed using the same technique with the addition of a captopril treatment arm. The Ang $\mathrm{II}_{\mathrm{ir}}$ secretion was pulsatile. After the $\mathrm{K}^{+}$concentration was increased from 3.6 to $9 \mathrm{mM}$, there was an increase of Ang $\mathrm{II}_{\mathrm{ir}}$ release from the $\mathrm{ZG}$ cells. Similar to our earlier studies, the average amount of $\mathrm{AII}_{\mathrm{ir}}$ secretion when the cells were superfused with $9.0 \mathrm{mM} \mathrm{K}^{+}$was $2.32 \pm 0.59$-fold of that with $3.6 \mathrm{mM} \mathrm{K}^{+}(25.42 \pm 11.47$ vs. $10.4 \pm 2.3 \mathrm{fM} / 15 \mathrm{~min} /$ $10^{6}$ cells ). Although administration of $20 \mu \mathrm{M}$ captopril reduced the average Ang $\mathrm{II}_{\mathrm{ir}}$ secretion $1.24 \pm 0.07$-fold $(20.0 \pm 8.2$ vs. $25.42 \pm 11.47 \mathrm{fM} / 15 \mathrm{~min} / 10^{6}$ cells $)$, the Ang $\mathrm{II}_{\mathrm{ir}}$ secretion during the first $60 \mathrm{~min}$ of superfusion was not altered $(20.3 \pm 4.1$

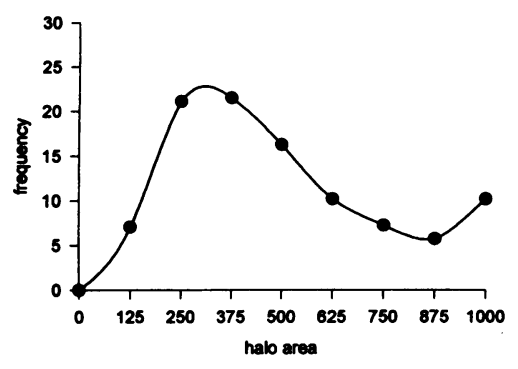

Figure 4. Frequency distribution of halo area of secretory cells depicted in Fig. 3.

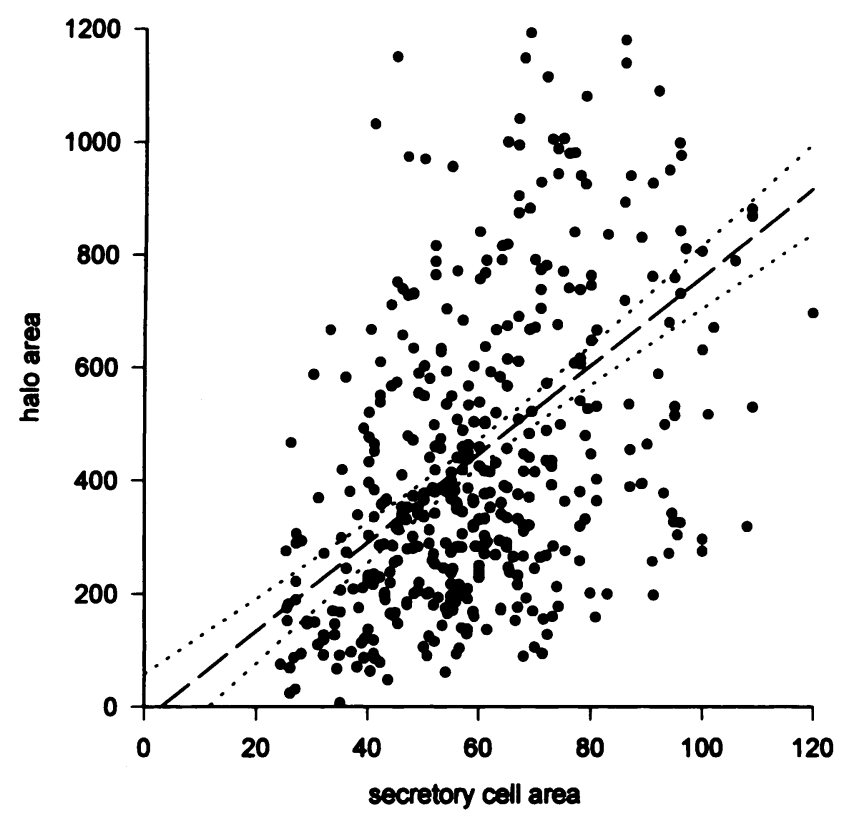

Figure 5. Relationship between cell area and halo area in the cells depicted in Figs. 3 and 4. There was a significant $(P<0.001 ; r$ $=0.566$ ) correlation between cell area and halo area. The dotted lines represent the $95 \%$ confidence intervals.

$\mathrm{fM} / 15 \mathrm{~min} / 10^{6}$ cells in the presence of captopril versus $21.4 \pm 7.1 \mathrm{fM} / 15 \mathrm{~min} / 10^{6}$ cells in its absence). The effect of captopril was consistently observed thereafter, producing a $1.40 \pm 0.03$-fold decrease in $\mathrm{AII}_{\mathrm{ir}}$ secretion from the high $\mathrm{K}^{+}$ control. The delayed onset of captopril's action was further verified by comparing its effect on the rates of Ang II and Ang I secretion (Fig. 6).

Cell blot study. The percentage of secretory cells did not change significantly when the $\mathrm{K}^{+}$concentration was increased to $9.0 \mathrm{mM}$ or when the cells were treated with $200 \mu \mathrm{M}$ captopril (Fig. 7). However, in those cells that secreted Ang II, high $\mathrm{K}^{+}$ concentration shifted the frequency distribution of halo area

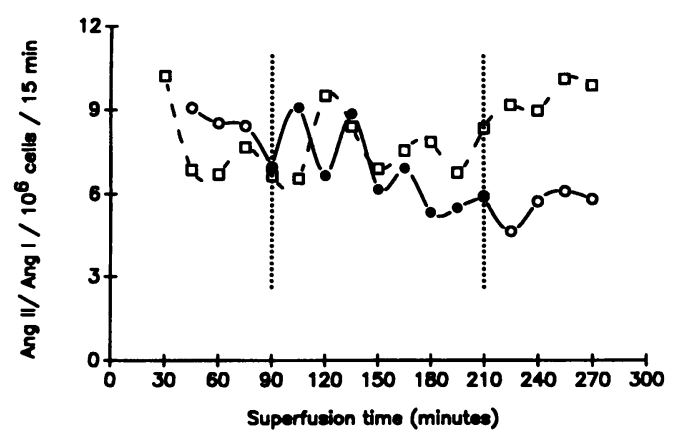

Figure 6. Ang II/Ang I secretion ratios in superfused ZG cells with and without captopril (representative results from one of two experiments). Captopril was added to the superfusion from 90 to $210 \mathrm{~min}$. Note that only after $60 \mathrm{~min}$ of superfusion with captopril does the ratio change. This change was produced by both a $20-25 \%$ decrease in Ang II levels and a $10-12 \%$ increase in Ang I levels, particularly in the hour after the captopril was stopped. Open boxes, control; closed circles, superfusion with captopril; open circles, before and after superfusion with captopril. 


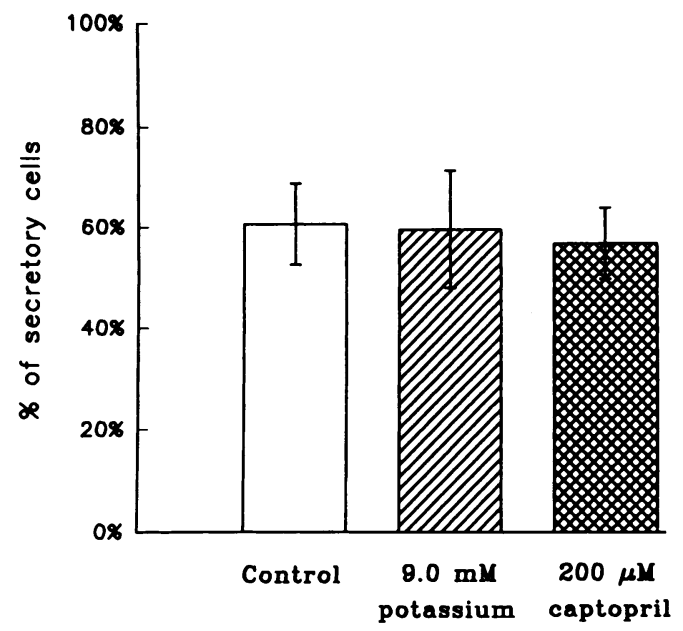

Figure 7. The percentage of secretory cells did not change significantly when the $\mathrm{K}^{+}$concentration increases to $9 \mathrm{mM}$ or when the cells were treated with $200 \mu \mathrm{M}$ captopril. Animals were on a normal (0.4\%) sodium diet. Mean \pm SEM, $n=4$ for $9 \mathrm{mM} \mathrm{K}^{+}, n=3$ for captopril.

toward higher values (Fig. 8). Indeed, the percentage of high secretors (defined as those cells with a halo area $>1,000 \mu \mathrm{m}^{2}$ increased $2.0 \pm 0.3$-fold $(P<0.01)$ when the cells were stimulated with a high concentration of $\mathrm{K}^{+}(n=4$ separate experiments). In contrast, captopril shifted the distribution toward lower values (Fig. 8). This was consistent with the findings that the average halo area was increased and reduced by $\mathrm{K}^{+}$ and captopril, respectively $\left(549.0 \pm 57.3 \mu \mathrm{m}^{2}\right.$ for the control, $644.6 \pm 89.5 \mu \mathrm{m}^{2}$ for $\mathrm{K}^{+}$stimulation, $443.2 \pm 18.5 \mu \mathrm{m}^{2}$ for captopril treatment, $P=0.028$ by Fisher exact test).

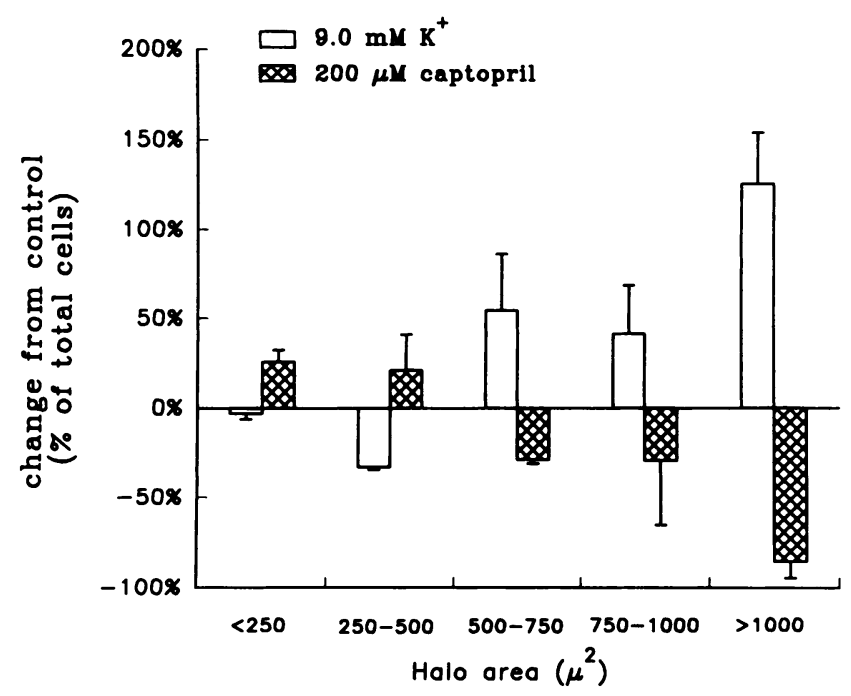

Figure 8. Changes from control of the frequency distribution of isolated ZG cells according to halo area. High $\mathrm{K}^{+}$concentration shifted the distribution toward higher values, while captopril shifted it lower. Similar shifts were observed in all the experiments $\left(n=4\right.$ for $\mathrm{K}^{+}$stimulation, $n=3$ for captopril treatment). These findings were compatible with those of the population studies where potassium increased and captopril decreased Ang II secretion.

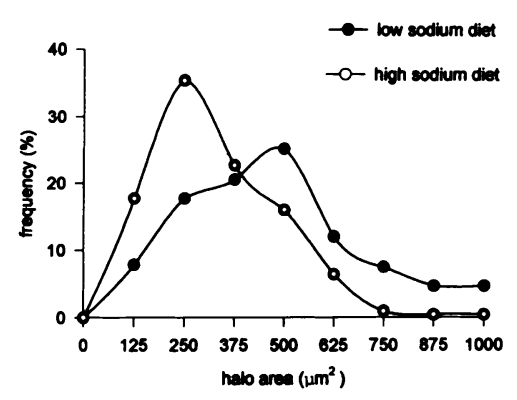

Figure 9. Frequency distribution of halo area in cells obtained from rats on a high sodium diet (open circles; six experiments, 525 cells) and on a low sodium diet (filled circles; four experiments, 375 cells). Note the substantial shift to greater secretion/cell on the low sodium diet.

Chronic response to low and high salt diet

Superfusion study. Ang $\mathrm{II}_{\mathrm{ir}}$ was secreted from superfused ZG cells in a pulsatile pattern for both low and high salt groups. ZG cells obtained from rats on a low salt diet consistently secreted more Ang $\mathrm{II}_{\mathrm{ir}}$ when compared with studies performed on cells from rats on a high salt diet $(1.85 \pm 0.58$-fold increase, $n=6, P<0.05)$. The average Ang $\mathrm{II}_{\mathrm{ir}}$ secreted was $62.7 \pm 18.9$ $\mathrm{fM} / 15 \mathrm{~min} / \mathrm{rat}$ from the high salt group and $129.6 \pm 67.0 \mathrm{fM} /$ $15 \mathrm{~min} /$ rat from the low salt group.

Cell blot study. There was a wide variation in halo areas both in sodium-loaded and sodium-depleted groups. However, the distribution pattern of the halo areas also was different in the two groups. The secretory cells obtained from sodiumdepleted animals produced larger halos and shifted the distribution curve to the right, while the ZG cells of sodium-loaded rats produced smaller halos (Fig. 9). The difference between the halo area produced by ZG cells of the sodium-depleted and sodium-loaded animals was significant (Mann-Whitney rank sum test, $P<0.001$ ). The median halo area was $399 \mu \mathrm{m}^{2}$ in the sodium-depleted group and $200 \mu \mathrm{m}^{2}$ in the sodium-loaded group. Note that cells obtained from animals on an ad libitum diet have a distribution in between these curves (Fig. 4). In contrast to the acute stimulation where no change in the percentage of secretory cells was observed, chronic stimulation of Ang II secretion by sodium depletion doubled the proportion of secretory cells. The percentage of Ang II-secreting cells was $26.0 \pm 2.5 \%$ after $5 \mathrm{~d}$ of high sodium diet ( $n=6$, independent experiments), versus $53.5 \pm 3.0 \%$ of cells from sodium-depleted rats $(n=4$ independent experiments; $P<0.01$ ) (Fig. 10).

\section{Discussion}

The adrenal gland is one of several organs in which a local renin-angiotensin system is present (1-8). The basic mechanisms of modulating peptide secretion, including Ang II release, are similar in various endocrine, autocrine, and/or paracrine cells. For example, moderately increased extracellular potassium concentration $(5-10 \mathrm{mM})$ is a secretagogue for insulin and Ang II. Cytosolic calcium or CAMP, the classic modulators of a regulated secretory pathway, are important regulators of active renin (and Ang II) secretion by various cells, including the juxtaglomerular and adrenal ZG cells (13-15). The secretion of Ang II via the regulated secretory pathway provides its prompt and precise release upon stimulation, often to modify local function rather than to have a systemic effect. However, to understand this potential local effect it is important to know how Ang II's secretion is regulated at a cellular level. In this study, we demonstrate that Ang II can be secreted directly from 


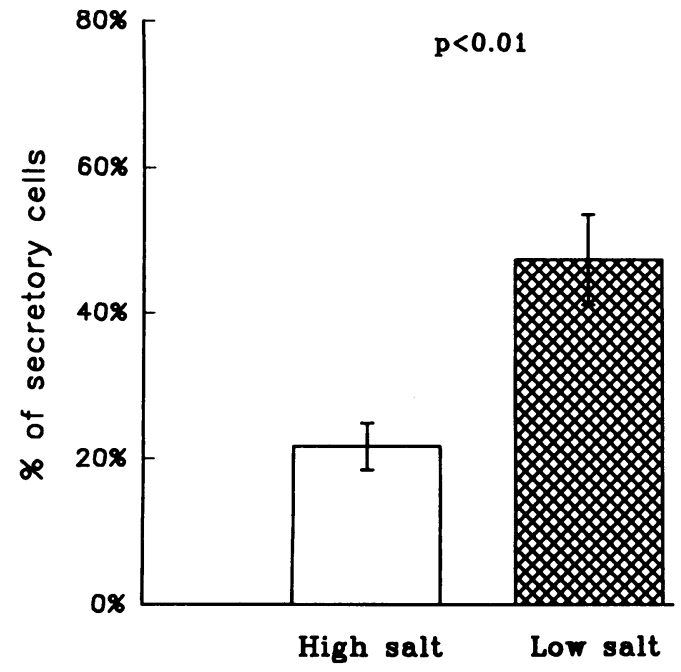

Figure 10. Chronic manipulation of dietary sodium content altered the percentage of secretory cells: $26.0 \pm 2.5 \%$ on the high sodium diet vs. $53.8 \pm 3.0 \%$ on the low sodium diet $(n=6$ for high sodium diet, $n=$ 4 for low sodium diet $)(P<0.01)$.

individual ZG cells. This is consistent with our previous findings that populations of enzymatically dispersed ZG cells secrete Ang II in a pulsatile pattern (9). Furthermore, the amount of Ang II secreted per cell but not the number of secretory cells can vary acutely. Contrariwise, both the percentage of secretory cells and the amount secreted per cell vary with chronic stimulation of aldosterone secretion.

Is all the immunoreactive material observed in the cell blot assay Ang II? The first antibody cross-reacts $100 \%$ with Ang III. However, this is not likely to be a problem in this study, since in our previous superfusion experiments (9) Ang III, assessed after HPLC purification, is not detected in the superfusate, and therefore it is unlikely to be a major product from the single cell. Our antibody also cross-reacts with Ang I, which is present in the superfusate. The halo could theoretically represent the secretion of Ang I. Indeed, by using an Ang I antibody in a hemolytic plaque assay, Ang I was shown to be actively secreted from juxtaglomerular cells of the kidney (16). However, at least two factors make it unlikely that this peptide is more than a minor contributor in the present study. First, in our previous experiments, the Ang I/Ang II ratio was only 1:5 in the superfusate, which was collected in a cocktail of inhibitors including captopril, PMSF, and EDTA and was frozen immediately to inhibit enzyme activity (8). Second, in this study, the treatment by captopril to block Ang I-Ang II conversion, and thereby presumably to increase Ang II levels, reduced rather than increased the halo area of the secretory cells.

We demonstrated that there is a proportional increase in stain intensity (IGV/area) on the polyvinyldiene difluoride membrane for Ang II concentrations ranging from $10^{-10}$ to $10^{-7}$ M. This suggests that we might be able to quantify the Ang II secreted from each cell. However, several factors make a quantitative rather than a semiquantitative estimate difficult. The tight first order relationship between halo areas and IGVs likely indicates that the concentration of Ang II per unit area has reached or exceeded the maximum of our measuring ability given our experiment conditions. This maximum can be influenced by the following factors: the capacity of Ang II binding by the membrane, the accessibility of the bound Ang II to the Ang II antibody, the affinity and capacity of the Ang II antibody to detect Ang II confined to an area on the membrane, the accessibility of the first antibody to the second antibody, and the accessibility of the substrate to its enzyme. Of particular importance is the realization that these factors are likely to be different when Ang II is applied from a micropipette as opposed to when it is secreted, a condition where other peptides and/or proteins are cosecreted and influence one or more of the abovementioned processes differently. Thus, we have not tried to precisely quantitate the amount of Ang II secretion from individual cells. In addition, the cell halo IGV/area did not match the maximal IGV/area observed by placing Ang II or albuminbound Ang II on the membrane.

By superfusing populations of cells we confirmed our previous findings (9) that acute administration of $\mathrm{K}^{+}$increases, while treatment with $200 \mu \mathrm{M}$ captopril inhibits Ang II secretion from isolated rat ZG cells. Of interest is the observation from our cell blot studies that these acute manipulations did not change significantly the percentage of Ang II-secreting cells. This suggests that the acute regulation of Ang II secretion by $\mathrm{K}^{+}$or captopril is likely achieved by changing the amount of Ang II secreted from individual secretory cells instead of recruiting new cells or inactivating existing secretors. This is supported by the finding that $\mathrm{K}^{+}$stimulation increased, and captopril treatment decreased, the number of high secretors (Fig. 8). The mechanism appears to be different for the regulation of Ang $\mathrm{II}_{\mathrm{ir}}$ secretion by dietary sodium intake. Chronic dietary manipulation changed the amount of Ang $\mathrm{II}_{\mathrm{ir}}$ secretion from individual cells similar to what occurred with the acute manipulations. In addition, the percentage of secretory cells also was altered to further modulate the total Ang $\mathrm{II}_{\mathrm{ir}}$ secreted. Since characterization of the cells after cell blotting is not possible, we do not know precisely what kind of cell is responsible for the Ang II production, or, perhaps as important, which cells in our preparation are nonsecretors. Previous studies (17), based on crude morphology and steroid production patterns, suggest that in general our preparation consists $90 \%$ or more of glomerulosa cells. However, further study to more precisely characterize the Ang II secretory cells is needed to answer this question.

The majority of nonsecretors stained more lightly than the secretors. The staining of nonsecretors could imply the attachment of Ang II from other cells to surface Ang II receptors with or without internalization. However, considering the setting of single cells out of the reach of Ang II (halos) from secretory cells, the use of serum-free medium, and the short time needed for receptor-mediated endocytosis and intracellular degradation of Ang II (18), this is an unlikely explanation. Since the cells in the assay lacking Ang II antibody were still faintly stained, the staining of nonsecretors could well represent the nonspecific binding of antibody, reagent, or substrate to the cells. In contrast, the dark nonsecretors could represent secretors which had been washed off their halo.

The viability of ZG cells was documented before the experiments by the trypan blue exclusion test. Although it was not possible to evaluate cell viability after incubation, the attachment of cells to the membrane, which requires an active cellular process, would suggest that the cells were still viable. However, the trypan blue exclusion test is not foolproof. Minor cellular damage that modified function, e.g., damage to cell surface receptors or minor membrane damage, could appear normal with this test. However, in this case the modulation of secretion, 
e.g., by potassium or dietary sodium, would not occur. In addition, in our previous superfusion experiments (9), the death of ZG cells was associated with the absence rather than the presence of secretion. Thus, it is unlikely that the Ang II secreted resulted from passive leaking of intracellular substances due to cellular injury. Typically, secretory peptides are present inside secretory granules attached to the microtubule system, and an active exocytosis involving fusion of the granules to the membrane is needed for their release (19). Although secretory vesicles may be released from permeabilized cells, they maintain the typical orientation of transport vesicles with their product sealed inside (20). Furthermore, several studies using permeabilized cells designed to study the active secretion of peptides suggest that leaking is an unlikely confounding variable $(21,22)$.

Why didn't captopril better inhibit Ang II production in the cell blot studies? One possibility is increased production of Ang I that cross-reacts with the anti-Ang II antibody. However, the cross-reactivity of Ang I with the Ang II antibody is $<0.1 \%$. Using the amount of Ang I found in our population studies, its production would be insufficient for this artifact to explain our results. A second possibility relates to the likelihood that a substantial proportion of the Ang II is formed intracellularly. If captopril enters the cell slowly or not at all, then it may have only a limited effect on Ang II production. Furthermore, even if it entered the cell, since Ang II is stored in granules, the time lag between Ang II's production inside secretory granules and the release of mature secretory granules could be as long as 45-60 min. This latter possibility seems most likely, given the results using superfused cells (Fig. 6). These results indicate that during the first hour of captopril treatment Ang II/Ang I was only minimally, if at all, modified. However, during the second hour and the hour after treatment, a reduction in Ang II levels and an increase in Ang I levels were observed.

In summary, we have demonstrated for the first time that Ang II is secreted from individual ZG cells. The findings obtained from the cell blot assay are consistent with those observed in the superfusion study both with acute and chronic manipulations. However, the cell blot assay provides additional insight into the cellular mechanisms involved by documenting that with acute manipulations Ang II secretion by individual cells changes, but the number of secretory cells is not modified. In contrast, with chronic dietary sodium changes, both the number of secretory cells and the amount secreted by each cell varies.

\section{Acknowledgments}

We would like to thank Dr. Peter Vassilev for the access to image analysis equipment and Dr. Stephen Quinn for helpful discussions. Ms. Barbara Smith provided expert editorial and secretarial assistance.

These studies were supported by National Institutes of Health grants 5R01HL-46373 and 5R01HL-45438. Dr. Chiou was supported by an institutional training grant (5T32HL-07609) from the National Heart, Lung and Blood Institute.

\section{References}

1. Ganten, D., K. Hermann, T. H. Unger, and R. E. Lang. 1983. The tissue renin-angiotensin system: focus on brain angiotensin, adrenal gland and arterial wall. Clin. Exp. Hypertens. Part A Theory Pract. A5:1099-1118.

2. Inagami, T., K. Mizuno, M. Naruse, M. Nakamaru, K. Naruse, L. H. Hoffman, and J. C. McKenzie. 1989. Active and inactive renin in the adrenal. Am. J. Hypertens. 2:311-319.

3. Doi, Y., K. Atarashi, R. Franco-Saenz, and P. J. Mulrow. 1983. Adrenal renin: a possible regulator of aldosterone production. Clin. Exp. Hypertens. Part A Theory Pract. A5:1119-1126.

4. Mendelsohn, F. A. O. 1982. Angiotensin II is concentrated or locally produced in rat adrenal gland. Clin. Exp. Pharmacol. Physiol. S7:3-7.

5. Campbell, D. J., and J. F. Habener. 1986. Angiotensinogen gene is expressed and differentially regulated in multiple tissues of the rat. J. Clin. Invest. 78:3139.

6. Husain, A., P. De Silva, R. C. Speth, and F. M. Bumpus. 1987. Regulation of angiotensin II in rat adrenal glands. Clin. Res. 60:640-648.

7. Racz, K., F. Pinet, J.-M. Gasc, T.-T. Guyene, and P. Corvol. 1992. Coexpression of renin, angiotensinogen, and their messenger ribonucleic acids in adrenal tissues. J. Clin. Endocrinol. \& Metab. 75:730-737.

8. Kifor, I., T. J. Moore, F. Fallo, E. Sperling, A. Menachery, C. Chiou, and G. H. Williams. 1991. The effect of sodium intake on angiotensin content in the rat adrenal gland. Endocrinology. 128:1277-1284

9. Kifor, I., T. J. Moore, F. Fallo, E. Sperling, C.-Y. Chiou, A. Menachery, and G. H. Williams. 1991. Potassium-stimulated angiotensin release from superfused adrenal capsules and enzymatically dispersed cells of the zona glomerulosa. Endocrinology. 129:823-831.

10. Kifor, I., C.-Y. Chiou, and G. H. Williams. 1992. Posttranslational regulation of angiotensin II secretion from rat zona glomerulosa. Endocrine Society 74th Annual Meeting. 610a. (Abstr.)

11. Chiou, C.-Y., I. Kifor, T. J. Moore, and G. H. Williams. 1994. The effect of losartan on potassium-stimulated aldosterone secretion in vitro. Endocrinology. 134:2371-2375.

12. Kendall, M. E., and W. C. Hymer. 1987. Cell blotting: a new approach to quantify hormone secretion from individual rat pituitary cells. Endocrinology. 121:2260-2262.

13. Peters, J., K. Munterm, M. Bader, E. Hackenthal, J. J. Mullins, and D. Ganten. 1993. Increased adrenal renin in transgenic rats, TGR(mREN2) 27, and its regulation by cAMP, angiotensin II, and calcium. J. Clin. Invest. 91:742-747. 14. Hackenthal, E., M. Paul, D. Ganten, and R. Taugner. 1990. Morphology, physiology and molecular biology of renin secretion. Physiol. Rev. 70:1067-1116.

15. Kurtz, A., H. Scholtz, and R. Della Bruna. 1990. Molecular mechanism of renin release. J. Cardiovasc. Pharmacol. 16:S1-S7.

16. Hunt, M. K., S. P. Ramos, K. M. Geary, L. L. Norling, M. J. Peach, R. A. Gomez, and R. M. Carey. 1992. Colocalization and release of angiotensin and renin in renal cortical cells. Am. J. Physiol. 263:F363-F373.

17. Haning, R., S. A. S. Tait, and J. F. Tait. 1970. In vitro effects of ACTH, angiotensin, serotonin, and potassium on steroid output and conversion of corticosterone to aldosterone by isolated adrenal cells. Endocrinology. 87:1147-1167.

18. Bianchi, C., A. Gutkowska, A. DeLean, M. B. Ballak, J. Anand-Srivastava, J. Genest, and M. Cantin. 1986. Fate of [ $\left.{ }^{125} \mathrm{I}\right]$ angiotensin II in adrenal zona glomerulosa cells. Endocrinology. 118:2605-2607.

19. Hanover, J. A., and R. B. Dickson. 1988. Organelles of endocytosis and exocytosis. In Protein Transfer and Organelle Biogenesis. R. C. Das and P. W. Robbins, editors. Academic Press, San Diego. 401-461.

20. Bennett, M. K., A. Wandinger-Ness, and K. Simons. 1988. Release of putative exocytic transport vesicles from perforated MDCK cells. EMBO (Eur. Mol. Biol. Organ.). J. 7:4075-4085.

21. Knight, D. E., and P. F. Baker. 1982. Calcium-dependence of catecholamine release from bovine adrenal medullary cells after exposure to intense electrical fields. J. Membr. Biol. 68:107-140.

22. Oetting, M., M. S. LeBoff, L. Levy, L. Swiston, J. Preston, C. Chen, and E. M. Brown. 1987. Permeabilization reveals classical stimulus-secretion coupling in bovine parathyroid cells. Endocrinology. 121:1571-1576. 